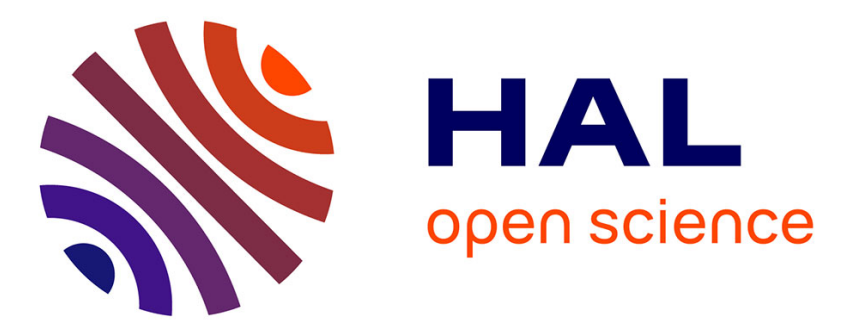

\title{
Web Communication of French Geoparks in Education: The Expression of Their Legitimacy
}

\author{
Aurélie Zwang
}

\section{To cite this version:}

Aurélie Zwang. Web Communication of French Geoparks in Education: The Expression of Their Legitimacy. Yves Girault. UNESCO Global Geoparks: Tension Between Territorial Development and Heritage Enhancement, Wiley; ISTE, pp.199-214, 2019, 9781786304858. 10.1002/9781119681489.ch11. hal-03324652

\section{HAL Id: hal-03324652 \\ https://hal.science/hal-03324652}

Submitted on 23 Aug 2021

HAL is a multi-disciplinary open access archive for the deposit and dissemination of scientific research documents, whether they are published or not. The documents may come from teaching and research institutions in France or abroad, or from public or private research centers.
L'archive ouverte pluridisciplinaire HAL, est destinée au dépôt et à la diffusion de documents scientifiques de niveau recherche, publiés ou non, émanant des établissements d'enseignement et de recherche français ou étrangers, des laboratoires publics ou privés. 


\section{Web communication of French geoparks in education: the expression of their legitimacy}

\subsection{Introduction: the value of a study of communication in education in French geoparks}

In France, in 2018, seven areas are labelled "UNESCO World Geoparks": the HauteProvence national nature reserve, the "massif du Luberon", the "massif des Bauges", the "Chablais", the "monts d'Ardèche", the "Causses du Quercy" and the Beaujolais. Based on the remarkable abiotic characteristics of the territory, this recognition, renewable every four years, often already takes effect on natural and/or cultural sites to be protected or enhanced in a superposition of heritage sites: the Luberon massif thus concentrates the classifications into regional natural park, geological natural reserve, biosphere reserve and European and world geoparks. More than half of French geoparks, namely the "Massif du Luberon", the Bauges, the "Monts d'Ardèche", and the "Causses du Quercy" are also regional natural parks. Geoparks are spaces set up and managed by a structure with a recognized legal status. They are made up of partners (associations, local authorities) who accept common missions, in accordance with the standards of certification. One of them is to adapt the population to natural, biotic and abiotic, or cultural, tangible and intangible heritage; education being a lever for local development policies (Barthes and BlancMaximin 2015), in particular through geotourism (Gonzalez-Tejada et al. 2017).

Chapter written by Aurélie ZwANG. The works presented in this chapter are part of the Geopark H2020 program. They were funded by the European Union's Research and Innovation Program Horizon 2020 under the Marie Sklodowska-Curie Grant Agreement No 644015 
Among the target audiences for geoparks' educational activities, schoolchildren are privileged. The evaluation item "Information and environmental education" (UNESCO 2016) is mainly oriented towards formal educational environments (university and school). In other words, in order to obtain the label, the geopark must be able to justify its active participation in school education for sustainable development (ESD), which addresses socio-environmental issues related to the territory and heritage. For its part, the National Education Department identifies and legitimizes certain educational resources for education for sustainable development (ESD) and communicates them to teachers via institutional websites (Zwang 2017). However, a search on these sites ${ }^{1}$ using the keywords " géoparc "/ "geopark" led to a very low occurrence in 2016 (two), a result that should probably be compared to the recent appropriation by the territories of this heritage approach (Hoblea et al. 2010) and therefore to a previously rather confidential dissemination to the general public.

French geoparks are thus faced with a dual problem of public recognition, sometimes in a context of hyper-patrimonialization, and a demand for deployment to formal educational environments. It is proposed to examine here how they respond to them through the notion of communication in education, defined as all productions worked with communicative intentionality and relating to educational, conceptual and organizational actors and frameworks, in a given context. This perspective focuses the point of view not on what is actually implemented in education for school audiences but on what is constructed and presented on education for these audiences. In short, it is not a question of looking at the "educational territory" as it is, but at the "educational map" as it is presented.

\subsection{A semiological and content analysis of communication in terms of website education for four French geoparks}

Communication in education can be studied through different documents: brochures, articles, catalogs, educational sheets and web pages. Assuming that the digital approach is now favored by teachers seeking information on available educational resources, a preliminary survey of online communication on geoparks was conducted in early 2017. It was established that there are information static websites on the one hand and profiles hosted on a social network allowing the reader to "love", "share" and on the other hand comment. In other words, either static websites built on the editorial intention of a main

\footnotetext{
1. These include the EDD competence center in Amiens, the EDD sites in life and earth sciences, history and geography, the academies of Aix-Marseille and Grenoble, as well as the national site and local territorial departments of Canopé (public operator offering services, resources and training to teachers).
} 
enunciator ${ }^{2}$ (Desprès-Lonnet and Cotte 2007) who can act, from a technical template, on the forms of communication, or dynamic websites where digital enunciators are multiple (Paveau 2017) but where the forms of writing are constrained by technosemiotic frameworks (Jeanneret 2014). In this case, the editorial enunciation of the screen page, i.e. the way in which the text is given to the reader to see and read by giving him a concrete and symbolic image, is totally predefined by the communication device (Jeanneret and Souchier 2005). While the research question focuses on the communicative intentionality of geoparks, only websites with an enunciator have been chosen, especially since labeling takes into account the existence of a "specific website with general information on environmental education in the territory" (UNESCO 2016).

The approach to the study of forms of communication in the education of French geoparks is semiological (Bonaccorsi 2016). It considers online documents in their scriptural and visual materiality, i.e. in the density of their editorial enunciation ${ }^{3}$. It is interested in their graphic universe through the colours and visual areas used and the iconicity of the text and the passing signs that allow the reader to click and move between the pages of the site (Souchier et al. 2003). It also focuses on identifying the brands of the editorial authority behind which the multiple actors of the established territory are based. It thus gives access to the symbolic and cultural dimensions worked by the enunciator, or in a way to his enunciation policy, in that it involves both his identity and his authority, here in the field of education.

On each website relating to the geoparks studied, an enunciating body merges into a "voice", that of the heritage entity, the proposals made by the various partners for school children. This educational content is analyzed according to dimensions (Zwang 2016):

- epistemological, i.e. its founding conceptions of education, its educational themes and its institutional frameworks;

- teleological, i.e. its aims and educational and strategic objectives;

- axiological, i.e. its environmental values and educational principles;

- praxeological, i.e. its methods, pedagogical approaches, means and tools.

This set is compared with the requirements of the National Education for Sustainable Development, with the last circular (Ministère de l'Éducation nationale 2015) as the main reference text.

2. The enunciator is the body identified as responsible for a statement.

3. The editorial statement is the set of contributions at the origin of the collective elaboration of an "image of the text", in the material sense (layout, format, typography, etc.) and in the figurative sense, in terms of its notoriety. 
Only the sites relating to the geoparks of the Luberon, Bauges, Chablais and Monts d'Ardèche were studied, with a collection of documents carried out between April 2017 and 2018. Barely certified, the geoparks in the "Causses du Quercy" and Beaujolais did not yet have structured communication in terms of education on the Web. As for the Haute-Provence geopark's site, it shows a communication on the subject limited to a few videos, in a breach of labelling standards probably explicable by its pioneering status. The study therefore focused on five Internet sites because for each of the four selected geoparks, the configurations are different: the Chablais geopark has a specific site, the Luberon and the Bauges have a common site for their geopark and their regional natural park, and for the Monts d'Ardèche, a site is dedicated to the geopark and an education portal is common with the regional natural park. The documents were collected from the education homepages to the following pages of the tree structure via the passing signs. This dynamic method is based on a usage logic. The corpus does not therefore meet an exhaustiveness criterion - $28 \%$ of the occurrence of "education" is included - but rather a qualitative logic, from generalities to more specific pages on education. The 58 documents studied (Figure 11.1) are web pages containing images, texts, maps and videos, and documents from an online port, also having an offline existence (Paveau 2015). The rare videos, not analyzed, would require a specific methodology.

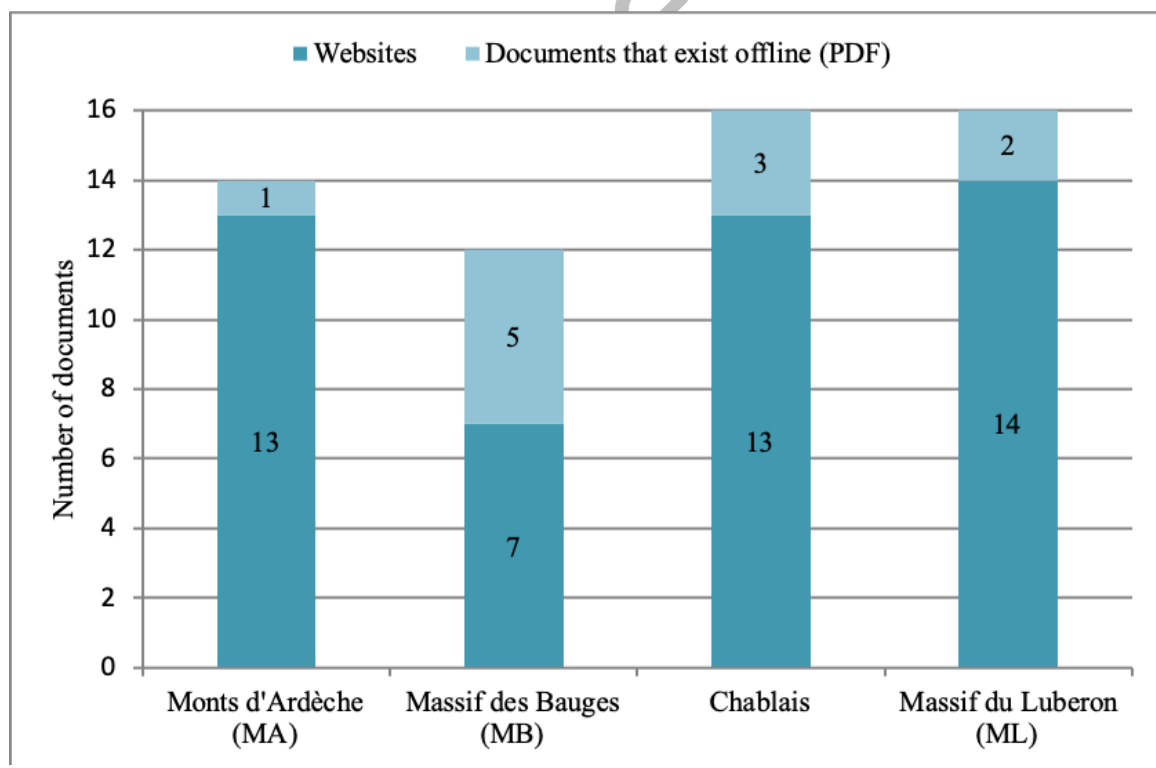

Figure 11.1. Number and distribution of online documents from websites (source: Zwang)

The results show that the educational communication of these geoparks is an expression of their legitimacy to educate the school public. 


\subsection{Justification in creating a site: the enunciation of the educational territory}

The Latin word situs means both the place and the extent of a country, a region. One of the functions of the website of the labeled territories is precisely to show the remarkable places and landscape characteristics on which their recognition is based. By extension, while the "need for a web page [is] to express its own thematic vocation, to be identifiable in its statements and purpose" (Candel et al. 2011, p. 174), the communicative intentionality perceptible on websites relating to geoparks is to denote and constantly connotate the territory concerned. Editorial choices converge to "make site" in the dual sense of the technosemiotic system and the geographical space to which it refers. Unifying the entire website, these editorial choices of territorial enunciation are not specific to the pages relating to education. Their operativity is nevertheless to place education in the singular topography of places and landscapes, by assigning it a place.

To open a web page of a site related to a geopark is to immerse yourself in a (geo)graphic environment. At the bottom of the page or in a banner, panoramas of landscapes are displayed. Functionalities allow the dynamic scrolling of photographs [MB 14; ML 1; ML 1; MA 2] with the objective of exposing the richness of the place. Designed as a scene, the background of the site houses a central text space, which can even be retracted by the reader (Figure 11.2). Without background photography or in addition, solid-coloured beaches, beige and brown for the rocks and soil of the Chablais (figure 11.3), or Parma for the Luberon of Provence and its lavender [ML 1], highlight a territoriality. The passing signs of the main menu are thus inscribed directly on the landscape or on coloured beaches connoting the territory [CHA 1; ML 1]. Sometimes arranged in "small forms of ideographic order" (Candel et al. 2011) containing an action verb and a pictogram representing a landscape element or an object [CHA 1; MB 1], they invite the visitor to explore, with his mouse and in the field: binoculars to "visit", a map to "discover", fir trees to "understand" (Figure 11.3).

In the case of Chablais, the "Geopark", an anglicism marking the international dimension of this recognition, is the only declaration of the website, which is materialized by the red logo of the banner. But in those of hyperpatrimonialized territories, named by the generic name of "park", a set of shapes and colors allows the identification of the editorial authority. In all cases, it is the regional natural park and not the geopark: the paratext of the Luberon massif site only presents the ovoid green star logo of the regional natural park [ML 1], a star which, on the word "Geopark" of the Ardèche mountains, signs the main declaration, which is reinforced by the green of the title and the side menu (figure 11.2). The same visual rubric chart is adopted by the Bauges site, which also uses

4. This notation corresponds to the references of the documents. 
green for hyperlinks [MB 1]. With the exception of the UNESCO logo, green thus seems to refer to the regional natural park as an embodiment of biotic nature, while red, a color also favored on the Chablais site in the subtitles and the side menu, seems to symbolize the telluric forces of abiotic nature (Figure 11.3).

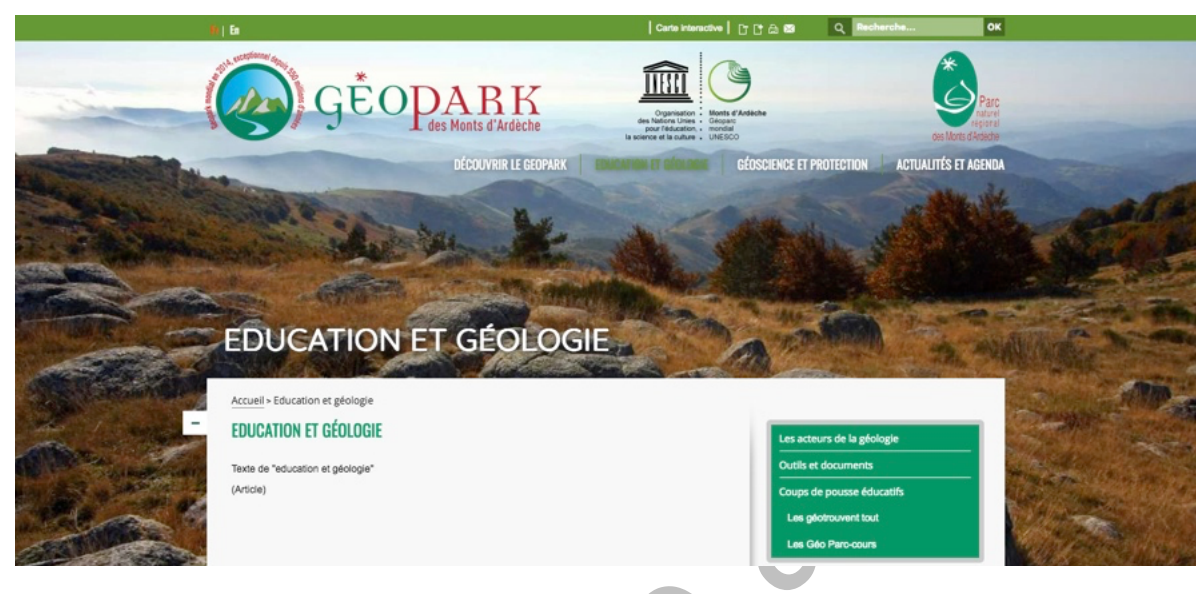

Figure 11.2 Extract from the site of the Ardèche Mountains Geopark [ARD 1]. The "-" sign allows the entire central frame to be retracted

We then enter educational territory through different paths that have the dual characteristic of stating the context and status of education, namely its physical and symbolic place. The site's tree structure speaks for itself in this regard. Thus on the site of the Luberon massif, a "education area" tab always registered at the top of the page gives permanent access to the pages located in the "daily to be preserved" section. In contrast to this preservation display and rather to enhance the value of the territory, in choices discussed further in section 11.4, the Bauges Massif site places education under a sub-section of the "Act" section: "Ensure the enhancement of actions". With a positive side, access to the education pages of the Chablais site is through "learning" and "knowing" it (Figure 11.3). As for the Ardèche mountains, although an education portal is entirely dedicated to it, the geopark site offers an "education and geology" section with no content on the home page (Figure 11.2). 


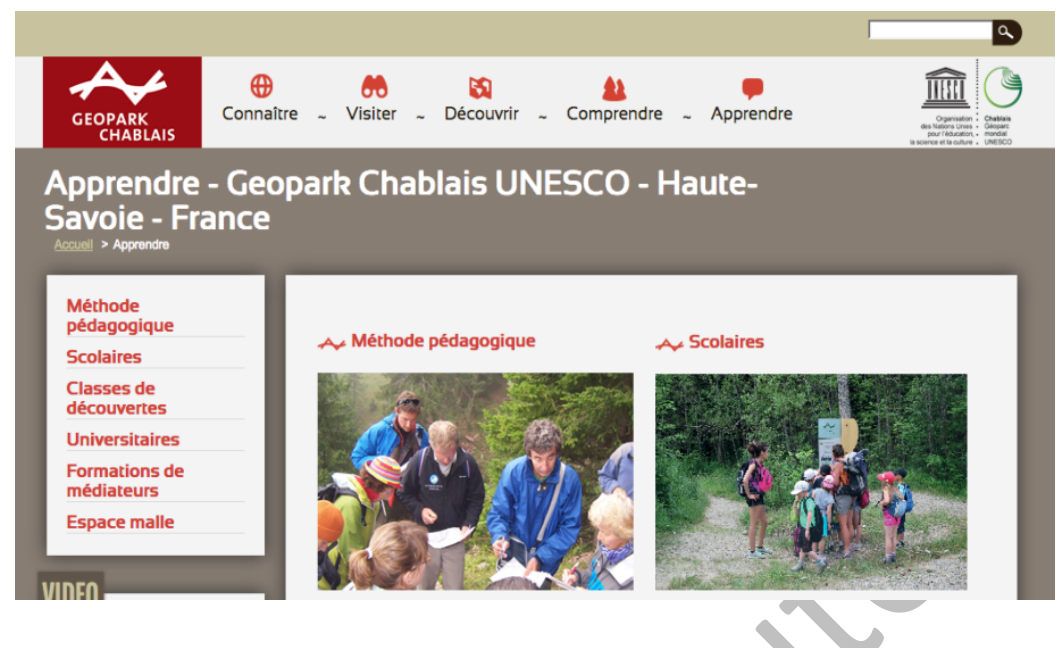

Figure 11.3 Extract from the home page on education in the Chablais geopark, in French (source: [CHA 1])

From the education home page, traffic is possible through side menus and the banner, but also, within the page, by an alignment of titled photographic thumbnails [CHA 1; ML $1 ; \mathrm{MB} ; \mathrm{MB} 1]$ and/or by lists of hyperlinks [MA 1; MB 1] directing to documents internal to the site or to the partners' sites. These arrangements give a visual impression of the multiplicity of places, actors and situations: the educational offer in the labelled territory seems excessive and varied. To reflect the diversity of educational interventions, the Chablais site presents a map with location icons showing all activities [CHA 2]. By placing them in a topography of labelled places and landscapes, the Chablais thus insists on their idiographical dimension, as a promise of pedagogical added value.

In fact, the territory as an educational field is shown through photographs that seem to capture pedagogical moments. On these images are drawn the characters of the educated and the educator whose characteristics are recurrent. The educated child is most often a child with a cap, integrated into a group and carrying out an activity (Figure 11.3): observing a landscape, taking notes, reading an interpretation panel, walking in single file, dancing and laughing... These testimonial representations accentuate the exhaustive effect of the educational offer and insist on the collegiality of the activities of heritage discovery. At the center of the groups, the educator is presented from the front and in an explanatory posture: he shows, speaks, seems concentrated in his task and captivates his audience (figure 11.3). It embodies the cultural and scientific mediation of the territory, the one in which the beneficiaries can have confidence. The educator absent 
from the images is, in contrast, the teacher. However, it is the target of communication in terms of education of geoparks websites with two main objectives.

The first objective is to indicate that the enunciative instance is at its service. For example, it proposes a "teacher's guide" [MA 3] where clicking on an outstretched hand provides an answer on education for sustainable development to a question formulated in the second person (Figure 11.4). The teacher is in fact the beneficiary to whom "tools" are systematically offered, most often in the form of an inventory: a title, a short description and one or more hyperlinks giving access to brochures or annual catalogues of the paid offer [ML 3; CHA 3], more rarely to free resources [MB 3].

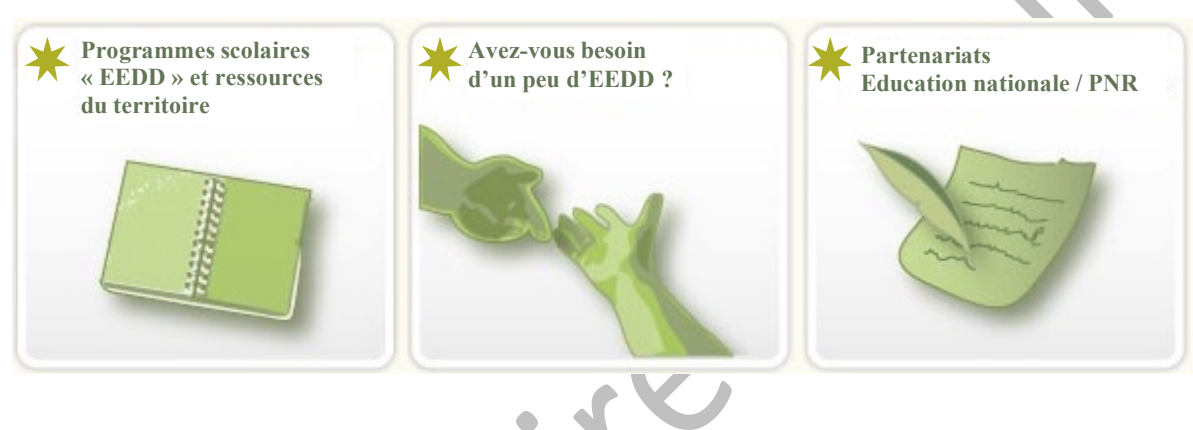

Figure 11.4 Excerpt from the "Teacher's Guide" page

of the MA portal, in French (source: [MA 3])

The second objective is to display the competence of the enunciator in education, an objective of educational legitimization that leads to a game of enunciations. It makes conspicuous elements whose interest and understanding are particularly relevant to teachers. It can devote a current page to the signing of an agreement with the French Ministry of Education [CHA 5] or a third of an A4 page to a testimony on an educational service [MB 4]. Similarly, links to school curricula can be a single item (Figure 11.4) or visually occupy half of each catalogue record in a table [CHA 3]. The partnership agreements with the French Ministry of Education are also very accessible (Figure 11.4), until they are the first documents to be downloaded from certain web pages [CHA 4; MB 2]. Their content is not editorialized in the graphic layout of the site, a contrast that materializes their authenticity, while also showing the logos and institutional signatories. Systematically included on offline documents for teachers, the National Education logos are the marks of the enunciator's educational legitimization (Zwang 2017). The editorial authority then becomes a pedagogical authority. This symbolic challenge can lead to an adaptation of the enunciator according to the content: the Bauges massif signs a geological booklet in the name of the geopark [MB 3] and indicates the two heritage features in a more general way [MB 5]. 


\subsection{Legitimizing by making sense: the statement of education for sustainable development in schools}

The analysis of the statements on the education of the websites of French geoparks according to the different dimensions of a unified educational theory for each territory shows that, beyond the specific territorial features advanced, convergence with education for sustainable school development is preponderant. By placing its content in a frame of reference that makes sense in terms of teaching professionalism, the educational offer of geoparks maximizes its chances of being solicited to educate schoolchildren.

The examination of the epistemological dimension shows that this paradox is rooted in the founding conceptions of labelled territories. Geoparks are part of an environmental education that most often considers the territory as a place of appropriation (Girault and Barthes 2016). Education is a means, "a tool at the service of a sustainable local development and planning project and a new social project" [ML 4, p. 16]; heritage spaces being defined with a strong economic importance: regional natural parks are "territories with high added value" [ML 4, p. 6] and "Geoparks [...] contribute to tourism and economic development" [MB 4]. However, "environmental and territorial" education for the school population is defined in local or national conventions that constitute the reference frameworks for their educational intervention. In order to reflect the legitimacy in place, enshrined in these frameworks, the enunciator of documents with an offline existence for teachers is identical to the signatory of the partnership. Thus, unlike Chablais, which has a specific agreement with the National Education Department under the aegis of the geopark [CHA 6], the Luberon massif and the portal of the Ardèche mountains only refer to the regional natural park because, in one case, the educational charter is exclusive to the regional natural parks of the Provence-Alpes-Côte d'Azur region [ML 4] and, in the other, without a specific agreement, the 2001 one between the regional natural parks and the national education authorities (figure 11.4).

At the same time, the themes of the geoparks are presented from a local perspective: the chestnut tree of the Ardèche mountains, the bories (dry stone huts) of the Luberon massif, the sharing of waters in the Bauges massif, etc. But an analysis of the supply of the five geoparks showed that with different proportions, i.e. more geology (water, landscape, geological history) and less agriculture and ecology, "all the themes [of the] secondary life and earth sciences programs [...] are represented in the main themes of the [...] geoparks. Geoparks therefore seem to be committed to providing an educational offer that responds to the themes proposed by the programs" (Serrÿn 2016, p. 62) (Table 11.1). 


\begin{tabular}{|c|c|}
\hline $\begin{array}{c}\text { Themes of biology and } \\
\text { geology school } \\
\text { programs }\end{array}$ & $\begin{array}{l}\text { Main themes of the educational offers of French } \\
\text { geoparks }\end{array}$ \\
\hline Issues and responsibility & Climate. Resources and energy. Territory. Issues. \\
\hline External geology & Erosion. Water. Landscape \\
\hline Internal geology & $\begin{array}{c}\text { Tectonics and geological history. Volcano. Petrology. } \\
\text { Risks and risks }\end{array}$ \\
\hline Fossils and evolution & Fossils \\
\hline Agriculture and soil & Agriculture and soil \\
\hline Biodiversity and ecology & Biodiversity and ecology \\
\hline
\end{tabular}

Table 11.1. Comparison of educational themes

(source: according to Serrÿn 2016, p. 61)

These results are consistent with the analysis of the teleological dimension. The educational objectives stated are common to those of the National Education Department, i.e. to educate for a responsible citizenship for the achievement of sustainable development. But the strategic objectives of the parks are specific to their challenges, namely "developing education in the territory among the public" [MA 6] by mobilizing teachers, qualified as "living forces" [ML 5, p. 2] to, as already noted above, "ensure the enhancement of actions"[MB 1]. Thus, the deployment of the school offer "is based on the opportunities of the territory to propose very concrete illustrations of the educational programs" [ML 8] or on a "pedagogical exploitation"[ML 4] of the geosites "with a view to obtaining the label" [MA 4]. At the same time, geoparks show support for national education to achieve its strategic objectives: the generalization of education for sustainable development is expressed by the idea of a "proactive policy of education for the environment and sustainable development" [ML 4, p. 8] and participation in steering committees [CHA 8] seems to contribute to increasing the number of institutions in the process of sustainable development [MEN 15]. As for the educational objectives, they agree on behavioural changes and, in particular, in Chablais, on the acquisition of knowledge. In addition, the new objective of "reconnecting students directly with nature" (Ministère de l'Éducation nationale 2015) can be reflected in the aims of geoparks for the appropriation of land and heritage, in an ethical oxymoron characteristic of the sustainable development paradigm (Bergandi and Blandin 2012).

The comparison of the axiological dimension between geoparks and national education shows the same alliance between a strong conservationist bias in 
environmental management and a more protective preservationism of nature. In the National Education, after a period of opposition to the currents of nature protection (Zwang 2016), the last circular (Ministère de l'Éducation nationale 2015) reintroduces "environmental education", the word "nature" as well as the ecocentric definition of the environment of the very first circular (Ministère de l'Éducation nationale 1977), without quoting it, which it juxtaposes with the one, anthropocentric of 2004 - "living conditions for man" - supposed to replace it. Similarly, in line with the ambivalence of UNESCO texts defining geoparks (Gonzalez-Tejada et al. 2017), the catalog of school supply in Le Chablais, for example, refers eleven times to the "riches" of the territory while at the same time issuing a code of good conduct to protect natural environments: "Do not pick wild flowers that are often fragile, moderate your crops [....], do not leave any traces [...]" [CHA 3]. Concerning educational principles, in response to the requirements of the National Education on the posture of neutral impartiality that teachers and partners must adopt (Zwang 2016), geoparks state that they "remain vigilant against any proselytism and participate in the development of critical thinking" [ML 4, p. 22] or that they "offer all guarantees in moral and pedagogical relations with students and teachers" [CHA 6, p. 7]. The purpose of communicating this code of ethics is to reassure people about their educational skills, as is the case with the display of accreditations by the National Education Department of people working in the field or host structures, which can be identified on a full page on education [MB 1] or within an exhaustive list that specifies the number and validity date of the accreditation [CHA 6].

The study of the praxeological dimension reveals a paradox between the display of specificities by geoparks and their conformity to the expectations of the French Ministry of Education. In contrast to "traditional" pedagogy [MA 5], they claim an active, fieldbased pedagogy, according to two main trends: in geoparks labelled regional natural parks, the "territorial approach" [ML 4, p. 18] is embodied rather in sensitive approaches: "feel, touch, listen to your environment but also travel, escape, love your territory" [ML 2] whereas in Chablais the approach is scientific and is part of the geological aspect of geotourism (Gonzalez-Tejada et al. 2017). The originality of the intervention proposals is expressed by neologisms in regional natural parks - "Topocontes" [MA 2], "Coup de pousse éducatif" [MA 4; ML 5], "Géo Parcs-Cours" [MA 4; MB 4], "pédagéologiques" [MB 1] and "géo-trouvent tout" [MA 4] - and in Chablais, the pedagogical method of recounting geological phenomena is qualified as "innovative" [CHA 7]. But geoparks show above all that their approaches are likely to meet institutional requirements. First, they constantly refer to the curricula and monitor the educational variations of the national education system: the Luberon massif specifies that "the reform of the colleges has given rise to the creation of a new axis of work around interdisciplinary practical teaching" [ML 6] and, to create the newly prescribed natural corners (Ministère de l'Éducation nationale 2015), it announces a target of 10,000 vegetable gardens and pedagogical gardens [ML 7]. Secondly, they highlight approaches 
advocated in education for sustainable development such as interdisciplinarity: "The richness of the pedagogical actions presented by the Geopark lies in its ability to build bridges between these different subjects" [CHA 3, p. 6]. Third, in Chablais, the constant reference to working with academics facilitates scientific legitimization (Zwang 2017) in response to the demand for "adapted" and "expert" resources (Ministère de l'Éducation nationale, 2015).

Finally, from the point of view of resources and while the economic aspect is the first criterion for educational legitimization (Zwang 2016), the free nature of certain offers or the assistance proposed for their financing is intended to encourage teachers to solicit geoparks, which is also facilitated by the provision of "relay teachers" paid by the National Education Department ${ }^{5}$. The partnership can take the form of hybrid educational tools between formal and non-formal education, such as the "Mon collège en Luberon" binder, published for each student in the territory and which remains in the life and earth sciences room [ML 8].

\subsection{Conclusion}

The analysis of communication in the field of education of French geoparks reveals tension between their enunciation and their statement. They constantly oscillate between the demonstration of a territoriality as the embodiment of an educational specificity and the adherence to the epistemological, axiological and praxeological frameworks of the National Education. In other words, outside the uniqueness of the instituted natural and cultural space, there would be a smoothing of education in the territory, which would be confirmed by the fact that, in the same territory, there is no apparent difference between education within the geopark and that in the regional natural park. The educational equivalence of these two heritage spaces would tend to show that it is less the heritage that penetrates the school space than the school that extends over the local space by an exemplification.

In an economic context of enhancement of the territory and professionalization of environmental education actors (Aspe and Jacqué 2012), which therefore links the search for educational legitimization to the development of a market, the observation made through this study therefore raises a more general question about what is being played out at the borders of the school world. While it is increasingly recognized that the introduction of "education to" disrupts the habitual teachers and the school form by a hybridization that would preferentially move from the non-formal educational sphere to the school (Barthes and Alpe 2018), it seems necessary to

5. Relay teachers are teachers who have a complementary mission in a cultural institution that is a partner of the French Ministry of Education. 
question in return how the search for educational legitimization by the partners of the school translates, in a hollow way, a definition by the school of legitimate culture beyond its walls.

\subsection{Bibliography}

Aspe, C., Jacqué, M. (2012). Environnement et société : Une analyse sociologique de la question environnementale. Maison des sciences de l'Homme, Paris.

Barthes, A., Alpe, Y. (2018). Les « éducations à », une remise en cause de la forme scolaire ? Carrefours de l'éducation, 45(1), 23-37.

Barthes, A., Blanc-Maximin, S. (2015). L'éducation au patrimoine, un outil pour un développement local durable, ou une instrumentalisation de l'éducation au service de la labellisation des territoires? Revue francophone du développement durable, 3, 8-22.

Bergandi, D., Blandin, P. (2012). De la protection de la nature au développement durable: genèse d'un oxymore éthique et politique. Revue d'histoire des sciences, 65, 103-142.

Bonaccorsi, J. (2016). Approches sémiologiques du Web. In Manuel d'analyse du Web, Barats, C. (ed.). Armand Colin, Paris.

Candel, E., Jeanne-Perrier, V., Souchier, E. (2011). Petites formes, grands desseins. D'une grammaire des énoncés éditoriaux à la standardisation des écritures. In L'économie des écritures sur le Web, Davallon, J. (ed.). Hermès-Lavoisier, Paris.

Després-Lonnet, M., Cotte, D. (2007). Nouvelles formes éditoriales en ligne. Communication et langages, 154, 111-121.

Girault, Y., Barthes, A. (2016). Postures épistémologiques et cadres théoriques des principaux courants de l'éducation aux territoires. Éducation relative à l'environnement : regards, recherches, réflexions, 13(2).

Gonzalez-Tejada, C., Du, Y., Read, M., Girault, Y. (2017). From nature conservation to geotourisme development: Examining ambivalent attitudes towards UNESCO directives with the global geopark network. International Journal of Geoheritage, 5, 1-20.

Hoblea, F. et al. (2010). Géosciences et projets de territoire: comparaison et conciliation de trois projets de géoparcs dans les Préalpes françaises du Nord. Géovisions, 37, 23-36.

Jeanneret, Y. (2014). Critique de la trivialité : les médiations de la communication, enjeu de pouvoir. Éditions Non standard, Paris.

Jeanneret, Y., Souchier, E. (2005). L'énonciation éditoriale dans les écrits d'écran. Communication et Langages, 145, 3-15. 
Ministère de l'Éducation nationale (1977). Instruction générale sur l'éducation des élèves en matière d'environnement. Circular, n 77-300 from 29 August.

Ministère de l'Éducation nationale (2015). Instruction relative au déploiement de l'éducation au développement durable dans l'ensemble des écoles et établissements scolaires pour la période 2015-2018. Circular, $n^{\circ}$ 2015-018 from 4 February.

Paveau, M.-A (2015). Ce qui s'écrit dans les univers numériques. Matières technolangagières et formes technodiscursives. Itinéraires, 2014(1).

Paveau, M.-A (2017). L'analyse du discours numérique : Dictionnaire des formes et des pratiques. Hermann, Paris.

Serrÿn, C. (2016). L'éducation dans les géoparcs mondiaux de l'UNESCO en France. Etude des offres éducatives proposées aux scolaires du secondaire dans les géoparcs mondiaux de l'UNESCO en France. Muséum national d'histoire naturelle, Paris.

Souchier, E., Jeanneret, Y., Le Marec, J. (2003). Lire, écrire, récrire : Objets, signes et pratiques des médias informatisés. Bibliothèque publique d'information, Paris.

UNESCO (2016). Grille d'autoévaluation des candidats au label des géoparcs de 2016. Formulaire d'auto-évaluation.

Zwang, A. (2016). La légitimation d'expositions itinérantes pour l'éducation au développement durable : des objectifs de l'École à ceux des producteurs. RDST, $13,21-49$.

Zwang, A. (2017). La communication environnementale légitimée pour éduquer au développement durable: de l'attente envers l'autorité éditoriale comme rapport de l'École à la trivialité. Questions de communication, 32, 105-124.

\subsection{Documents cited from the corpus}

The last consultations were held in August 2018.

\section{Monts d'Ardèche - Geopark site and education portal}

[MA 1] www.geopark-monts-ardeche.fr/education-et-geologie-geopark.html.

[MA 2] http://education.parc-monts-ardeche.fr/.

[MA 3] http://education.parc-monts-ardeche.fr/-Le-guide-de-l-enseignant-.html.

[MA 4] www.geopark-monts-ardeche.fr/education-et-geologie-geopark/coups-de-poussegeopark/les-geo-parc-cours-geopark.html.

[MA 5] http://education.parc-monts-ardeche.fr/-Avez-vous-besoin-d-un-peu-d-EEDDhtml?retour=back. 
[MA 6] www.education.parc-monts-ardeche.fr/L-action-educative-du-parc.html?retour= back.

\section{Massif des Bauges}

[MB 1] www.parcdesbauges.com/fr/agir/que-fait-le-parc/assurer-la-mise-en-valeur-desactions/education-au-territoire.html.

[MB 2] www.parcdesbauges.com/fr/documentation-education-au-territoire.html.

[MB 3] www.parcdesbauges.com/images/contenus/agir/que-fait-parc/assurer-mise-val eur-actions/Educ-territoire/livret_geol/Livret_peda_geologie_5e_avril_2014.zip.

[MB 4] www.parcdesbauges.com/images/contenus/agir/que-fait-parc/assurer-mise-val eur-actions/Educ-territoire/appel_projet/GEOPARCOURS collegiens2016.pdf.

[MB 5] www.parcdesbauges.com/images/contenus/agir/que-fait-parc/assurer-mise-val eur-actions/Educ-territoire/appel_projet/2018/PP_une_\%C3\%A9cole-un_site_pdf.

\section{Chablais}

[CHA 1] www.geopark-chablais.com/pedagogie.html.

[CHA 2] www.geopark-chablais.com/images/pedagogie/cartes_offre_globale18-19.jpg.

[CHA 3] www.geopark-chablais.com/documentation/32--4.html.

[CHA 4] www.geopark-chablais.com/pedagogie/scolaires.html.

[CHA 5] www.geopark-chablais.com/geopark-chablais/actualites/170-educationsignature-d-une-convention-avec-l-education-nationale.html.

[CHA 6] www.geopark-chablais.com/images/pedagogie/PJ5___Convention_de_par tenariat_DSDEN_Geopark.pdf.

[CHA 7] www.geopark-chablais.com/pedagogie/une-methodologie-innovante.html.

[CHA 8] www.geopark-chablais.com/geopark-chablais/actualites/180-le-geopark-membredu-copil-e3d-unesco-du-college-du-bas-chablais.html.

\section{Massif du Luberon}

[ML 1] www.parcduluberon.fr/quotidien-a-preserver/education-au-territoire-2/.

[ML 2] www.parcduluberon.fr/top-menu/espaces-elus/espace-education/.

[ML 3] www.parcduluberon.fr/quotidien-a-preserver/education-au-territoire/program me-dactions-educatives-2016-2017/. 
[ML 4] www.parcduluberon.fr/wp-content/uploads/2017/01/EET_Charte_Education Territoire.pdf.

[ML 5] www.parcduluberon.fr/wp-content/uploads/2017/03/EET_PA2016-2017.pdf.

[ML 6] www.parcduluberon.fr/un-quotidien-a-preserver/education-au-territoire/progr amme-dactions-educatives/les-plus-pour-le-second-degre/.

[ML 7] www.parcduluberon.fr/10000coinsnature/.

[ML 8] www.parcduluberon.fr/colleges-et-lycees-du-parc-du-luberon/mon-college-enluberon/. 